\title{
Preventive effect of novel nanomicelle of silymarin on liver injury induced by carbon tetrachloride in rat
}

Yasaman Safian Isfahani ${ }^{1}$, Abolfazl Aslani ${ }^{2}$, Mohammad Reza Memarzadeh ${ }^{3}$, Mohammad Hosein Aarabi $^{4}$ 1. MSc Student, Department of Clinical Biochemistry, School of Pharmacy \& Pharmaceutical Sciences, Isfahan University of Medical Sciences, Isfahan, Iran. ORCID ID: 0000-0003-2563-4408

2. Associate Professor, Department of Pharmaceutics, School of Pharmacy and Novel Drug Delivery Systems Research Center, Isfahan University of Medical Sciences, Isfahan, Iran. ORCID ID: 0000-0002-3290-6806

3. PhD of Analytical chemistry, Barij Essence Medicinal Plants Research Center, Kashan, Iran. ORCID ID: 0000-0001-59659182

4. Associate Professor, Department of clinical Biochemistry, School of Pharmacy and Pharmaceutical Sciences, Isfahan University of Medical Sciences, Isfahan, Iran., (Corresponding Author), Tel: 031-37927052, E-mail: mh.aarabi@pharm.mui.ac.ir, ORCID ID: 0000-0001-5377-178X

\begin{abstract}
Background and Aim: Silymarin is used for the treatment of liver disease due to its hepatoprotective effects. however, the use of its extract is limited due to poor aqueous solubility and low bioavailability. This study aimed to prepare a new formulation of silymarin and to evaluate its hepatoprotective effect after liver injury induced by carbon tetrachloride in rats.

Materials and Methods: In an experimental study, a new form of silymarin was prepared. A total number of 24 rats were divided into 4 groups. The two treatment groups were administered with silymarin extract and silymarin nanomicelle for 14 days before being damaged by $\mathrm{CCl} 4$. At the end of the study, blood samples were collected to determine serum levels of alanine aminotransferase (ALT), aspartate aminotransferase (AST), alkaline phosphatase (ALP) and, lipid profile. Moreover, antioxidant and oxidative stress enzyme activities were assessed in hepatic tissue. A one-way ANOVA test was used for statistical analysis.

Results: The activity of ALT and AST liver enzymes and the level of lipid profile parameters were significantly decreased in nanomicelle treated group compared to the silymarin-treated group $(\mathrm{P}<0.05)$. Also, the activity of liver antioxidant enzymes superoxide dismutase (SOD) and catalase (CAT) in the nanomicelle treated group showed a significant increase compared to the silymarin extract $(\mathrm{P}<0.05)$. The level of the Liver MDA was significantly decreased in the nanomicelle group compared to the silymarin extract $(\mathrm{P}<0.05)$.

Conclusion: The results of this study showed that silymarin nanomicelle has better hepatoprotective effects in ameliorating $\mathrm{CCl}_{4}$ toxicity in rats compared with extract of silymarin. Keywords: Silymarin, Oxidative Stress, Superoxide Dismutase, Hepatotoxicity, Nitric Oxide Received: Dec 3, $2019 \quad$ Accepted: Nov 20, 2020

How to cite the article: Yasaman Safian Isfahani Abolfazl Aslani, Mohammad Reza Memarzadeh, Mohammad Hosein Aarabi. Preventive Effect of Novel Nanomicelle of Silymarin on Liver Injury Induced by Carbon Tetrachloride in Rat. SJKU. 2021;26(2):1-11.

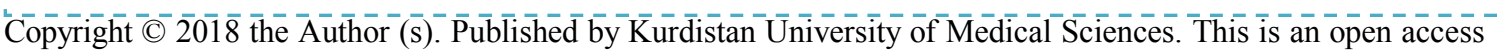
article distributed under the terms of the Creative Commons Attribution-Non Commercial License 4.0 (CCBYNC), where it is permissible to download, share, remix, transform, and buildup the work provided it is properly cited. The work cannot be used commercially without permission from the journal
\end{abstract}


بررسى اثر محافظتى نانوميسل جديد سيليمارين بر آسيب كبدى القاء شده با كربن

\section{تتراكلرايد در موش صحرايى}

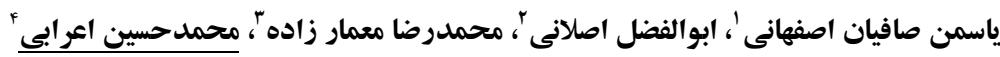

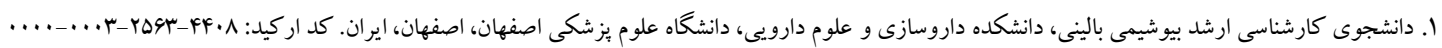

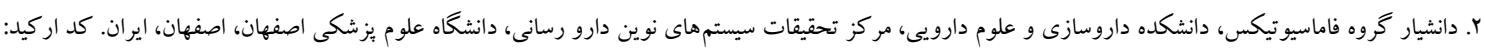

.........r-rYq.-91.9

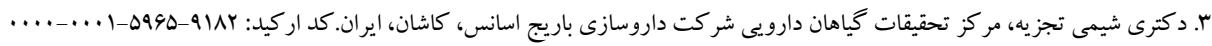

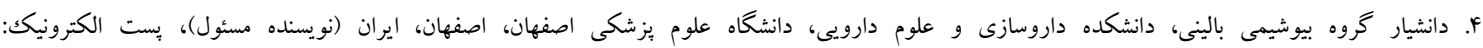
mh.aarabi@pharm.mui.ac.ir

جكيده

زمينه و هدف: سيليمارين به دليل اثرات حفاظت كبدى در درمان اختلالات كبدى استفاده مىشود؛ اما استفاده از عصـاره آن بـه

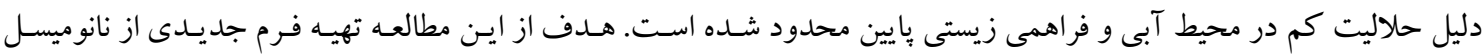

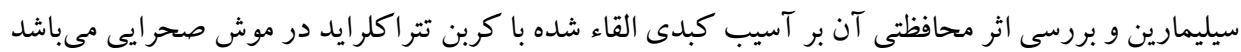

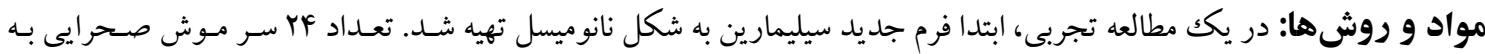

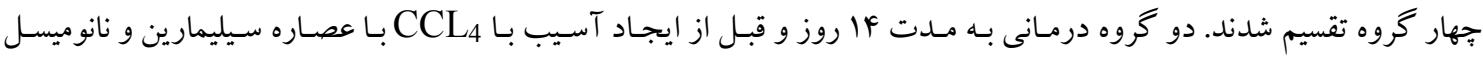

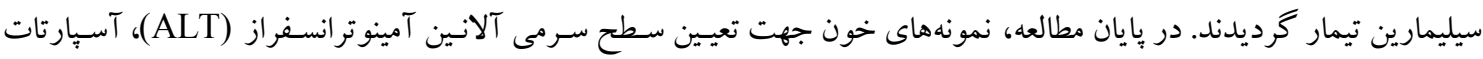

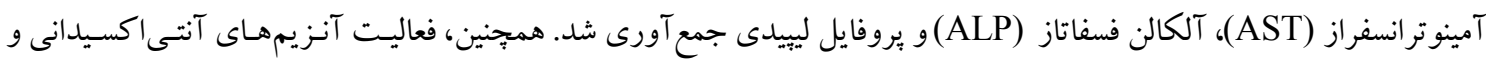

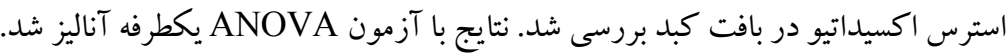

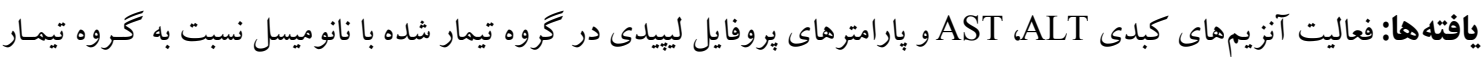

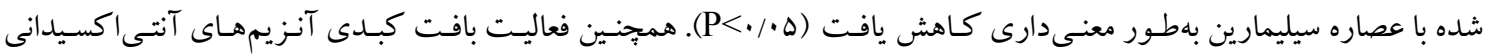

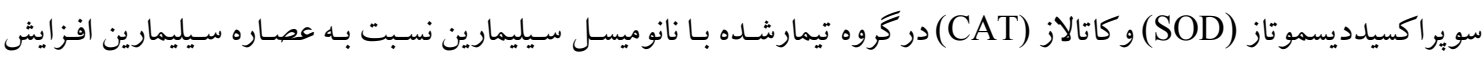

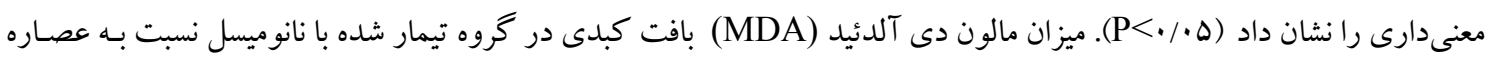

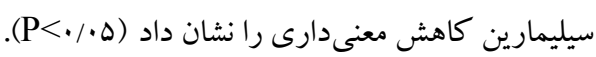
نتيجه كيرى: نتايج در اين مطالعه نشان داد، نانو ميسل سيليمارين داراى اثرات حفاظت كبدى دارى بهترى نسبت به عصاره سيليمارين در تعديل اثرات سميت القاشده بالCCL4 در موشها مىباشد.

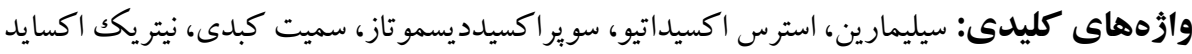

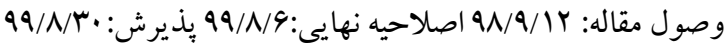


در مايع معده، جذب كم آن در روده و كوتاه بودن نيمهعمر خود فلاونوئيدها، باعث كاهش غلظت خـونى سـيليمارين و متعاقب آن، كـاهش غلظـت آن در رسـيدن بـه انـام هـدف مى شود و همين امر باعث محدود شــدن اسـتفاده از آن شـده است(1). وجـود ايـن محـدوديت، موجـب انجـام تحقيقـات كستردهاى جهت افزايش محلوليت، فراهمى زيستى و جذب . آن كرديده است. نتيجه اين يـروهشهـا منجـر بـه طر احسى و تهيه انواع فرمولاسيون براى سيليمارين كرديده اسـت كـه از

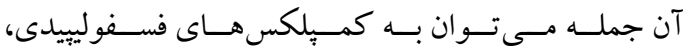

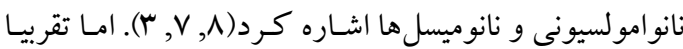
تمام اين روش ها بيجيجده و برهزينه مىباشند. هدف ما در اين مطالعه، براى اولين بار، تهيه فرم ساده، كمهزينه و جديدى از سيليمارين به شكل نانوميسل با قابليت انحلال و جذب بيشـر مى باشد. علاوه بر اين اثرات اين فرم جديد نسبت به عصساره سيليمارين بر خاصيت حفـاظتى سـلولهـاى كبـدى در برابـر سميت CClF، مورد بررسى و مقايسه قرار مى گيرد.

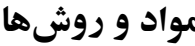

در اين مطالعه تجربى، عصاره سـيليمارين از شـركت سـيخما آلدريج (Sigma Aldrich) و مـواد ديخـر مثل يلسىاتسلن

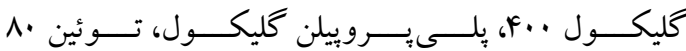
و كليسيرين از شركت Merck (TWEEN80) شد. به منظور رسيدن بـه بهتـرين فرمولاسـيون جهـت تشكيل يكك نانوميسل يايدار نسـبتهـاى مختلفـى از امولسـيفايرها و حلالها همـراه بـا عصـاره سـيليمارين تر كيـب شـدند (نتايج منتشر نشده اسـت). نانو ميسل سـيليمارين NFSM) New F. ب. با استفاده از بلى اتيلن كليكـول بهعنوان حلال و توئين ·ي بهعنـوان امولسـيفاير بـا روشهـاى

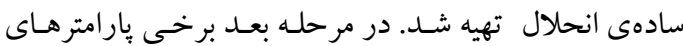
دارويى لازم براى نانوميسل، مانند اندازه ذرات، توزيع اندازه ذرات(Polydispersity index (PDI)، بــاســفـاده از تكنيـكSDynamic light scattering (DLS، ميـزان محصورسازى(Entrapment Efficiency (EE\% و ميزان
مقدمه

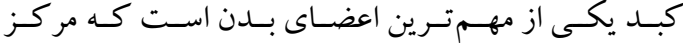
واكــش هــاى بيوشـيميايى ضــرورى و محسـل متابوليســم داروهاست و نقش مهمى را در سمزدائى و دفع زنوبيو تيكهاى متعدد و انواع داروها دارد؛ بنـابر اين آسـيب يـا تخريـبـ كبــ يِيامـدهاى شــديدى رادر سـلامت فـرد مبـتلا ايجــاد مى كند( (1). اين آسيب ها به علل مختلفى ازجملـه اسـتفادهى مداوم از الكل، هياتيتهاى ويروسى، بيمارىهاى متابوليكك ارثى، سموم محيطى، استفادهى نادرسـت دارويسى و...ايجـاد

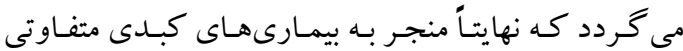
ازجمله هياتيت، فيبروز، سيروز، نكروز، سـرطانهـاى كبـدى و... مى شود(Y). امـروزه مطالعه و درمـان اخـتلالات كبـدى توسط گياهان و تر كيبات گياهى با توجه به امكان دسترسى بيشتر و عوارض جانبى كمتر نسـبت بـه درمـانهـاى دارويسى موردتوجه بيشترى قرارگرفته است(Y). ازجمله اين تركيبات كياهى، بلى فنولها هستند كه بـه وفـور در گياهـان مختلـف يافت مى شوند و به نظر مىرسد نقـش عمــدهاى در حفاظـت كياهان از آسيبهاى محيطى مانند اشعه فرابنفش خورشيد يا

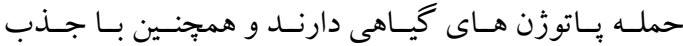
راديكالهاى آزاد نقش بسيار مهمى در سلامت انسانهـا ايفـا مىنمايد(f, (F). سيليمارين يكى از تر كيبات يلى فنول اسـت كه اثرات آنتى اكسـيدانى و ضـد سـرطانى آن مـدت هاسـت موردتوجه و بررسى قرارگر فتـه اسـت و بـهــوبى مسى توانــ به عنوان يكك مهار كنندهى راديكال آزاد و متعاقب آن مهار ير اكسيداسيون ليييد ها عمل كنـد. عـلاوه بـر اين،سـيليمارين ورود مو اد سمى مانند آفت كشهـا، فلـزات ســكين و CClY به سلولهاى كبدى را متوقف مى كنـد؛ بنـابر اين از آنهـا در برابر آسيبدهاى بعدى محافظت مى كند(9).

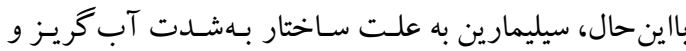
غير يونى در آب نـامحلول اسـت و تنهـا ·ب تـا •هدرصـد از سـيليمارين خـوراكى از دستخگاه كـوارش جـذب مسى شـود؛ بنابراين اثر خـوراكى سـيليمارين بـر عملكـرد كبـد بـه علـت محلوليت ضعيف، فراهمى زيستى يايين، تخريـب جزئسى آن 
تسرى كليسـيريد (TG) و آلبـومين (ALB) بــا اسـتفاده از كيتهاى تجارى بـر اسـاس روشهـاى آنزيماتيكك و رنـك سنجى ذخيره گرديـد. بـا استفاده از وسـايل جراحى، كبـد

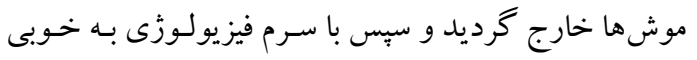

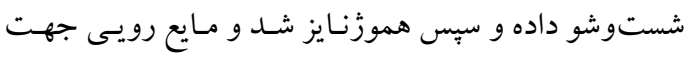

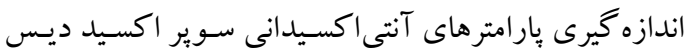
موتاز (SOD)، كاتـالاز (CAT)، كلوتاتيون براكسيداز و ميزان نيتريك اكسايد (GPx)

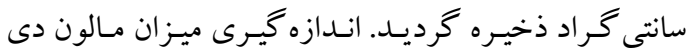
آلدهيد (MDA) با استفاده از تيوباربيتوريك اسيد (TBA)

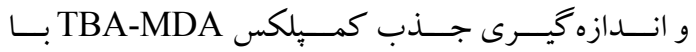
اسبكتروفتومتر در طولموج بrهه نانومتر قرائت گرديد. تمـام دادههاى مربوط بـه تأثير نانوميسل و عصـاره سـيليمارين بـر بارامترهاى بيوشيميايى سرم و فعاليت سيستم آنتى اكسيدانى و استرس اكسيداتيو بافت كبد كمى بوده و جهت نرمالبوديون دادهها از آزمون Kolmogorov-Smirnov استفاده شد.

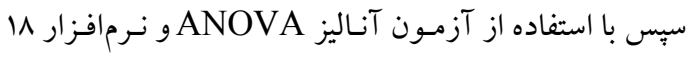

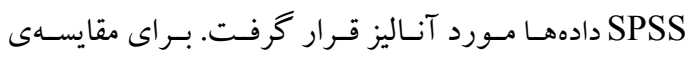

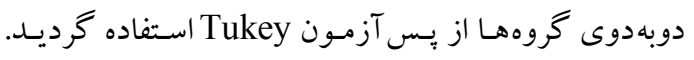

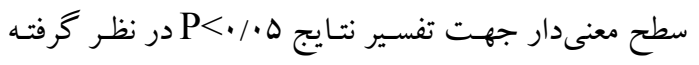

يافتهها 1- إنهيه و ارزيابى نانوميسل:

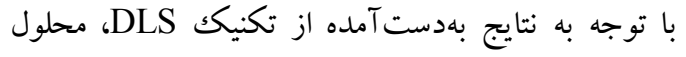

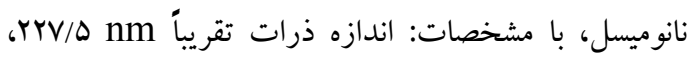

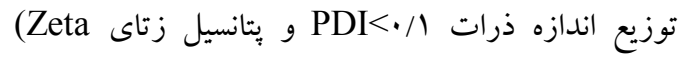
محلول برابر 1/90- (نشاندهنده تشكيل نانو ذرات مناسب و هموزن است) تهيه گرديد. ميزان

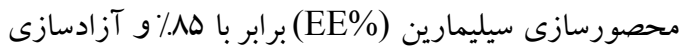

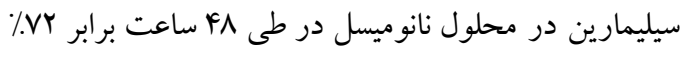

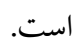

آزادسازى سيليمارين (In Vitro Release) در نانوميسل، مـورد بررسى و ارزيـابى قـرار گرفـت. يـس از تهيـه و تائيسد نانوميسل، كار حيوانى بر اساس مطالعه قبلى(Y)، با استفاده از

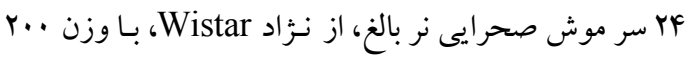

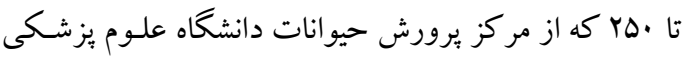

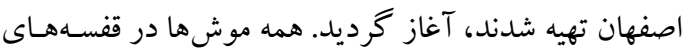

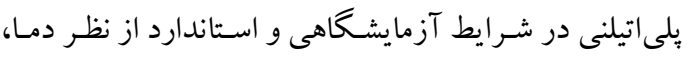

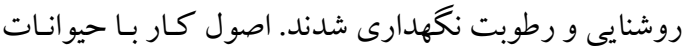
آزمايشگاهى مطابق با دستورات كميته اخلاق دانشكاه علوم يزشـكى اصـفهان رعايـت شـــ ايسن حيوانـات بـه صـورت

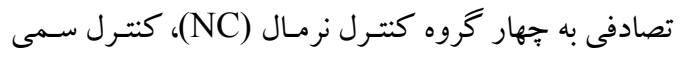

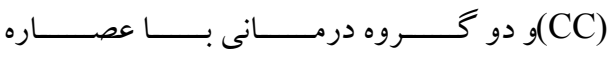
سيليمارين (SM+CMC) و نانوميسـ (NFSM) تقسيم

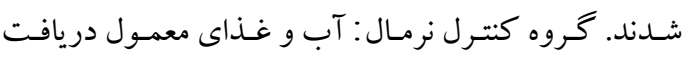

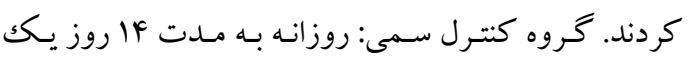

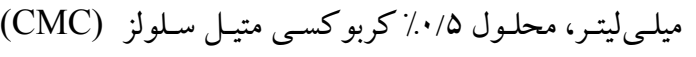

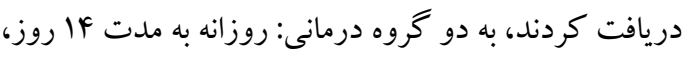

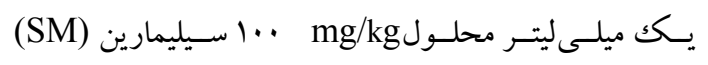

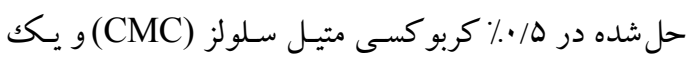

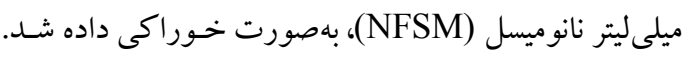

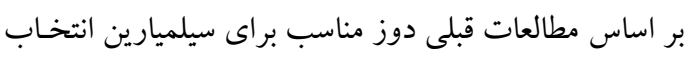

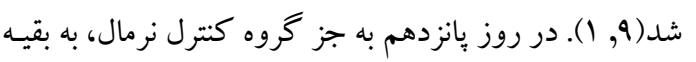

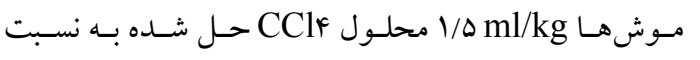

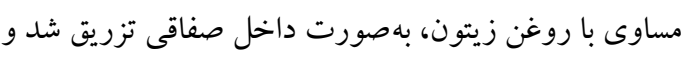

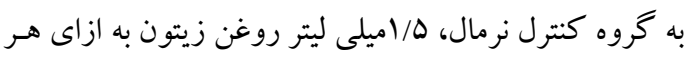

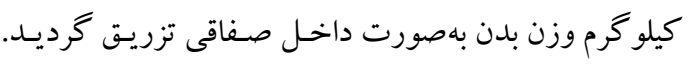

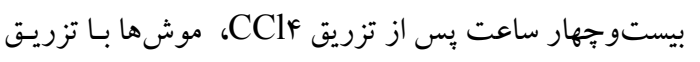

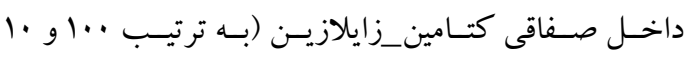

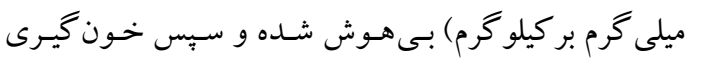

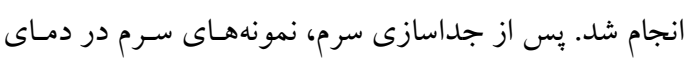

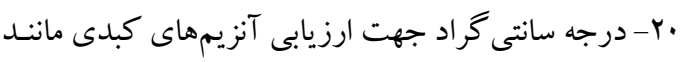

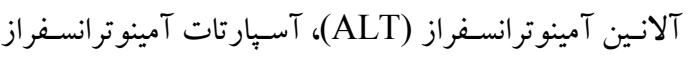

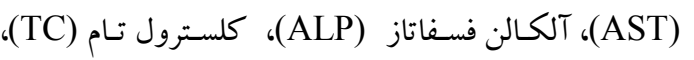


كروه درمانى (عصاره سيليمارين و نانوميسل) نسبت به گروه

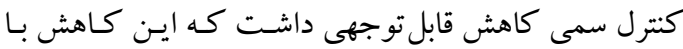

م معنى Pار تلقى مى شود. همانطور كه در نمودار

مشخص است، نانوميسل سيليمارين اثر بهبودى بيشترى را فرا نسبت به عصاره سيليمارين در فعاليت سرمى آنزيم ALT و

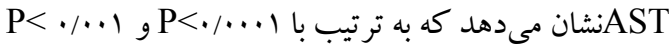
معنى دار محسوب مىشود. يافته ديخـر در ايـن نمودار ايـ

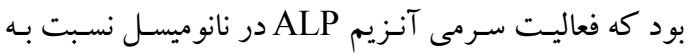
عصـاره سـيليمارين بـا ه./P> تفــاوت معنسى دارى نسـدارد

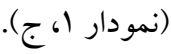

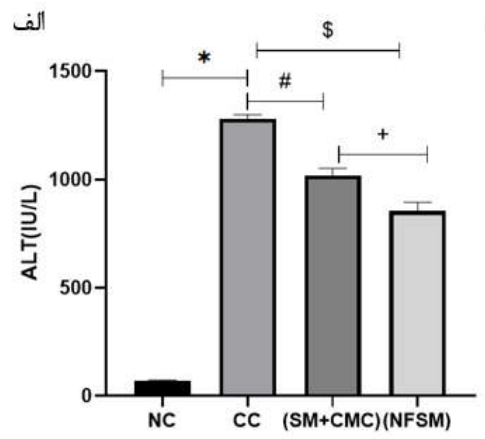
ب

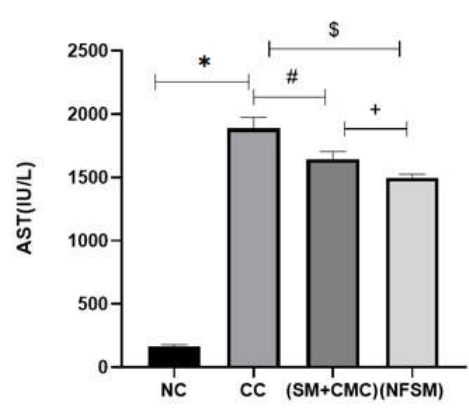

r- اثـر محلـول خـوراكى جديـــ و عصـاره سـيليمارين بـــ

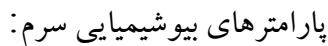
نتايج حاصل از اين مطالعه در مورد آنزيمهـاى كبـدى نشـان

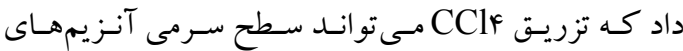
AST,ALT,ALP را در مقايسه با گروه نرمـال بـهصورت

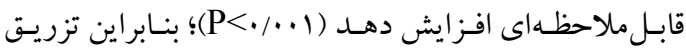
داخل صفاقى CClk بـهـورت تكك دوز توانست بـهطور موفقيـت آميزى سـميت مـوردنظر رادر سـلولهـاى كبـدى

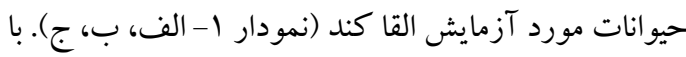

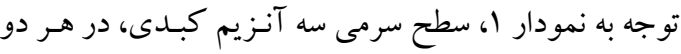

نمودار ا. اثر نانوميسل خوراكى در مقايسه با عصاره سيليمارين بر آنزيمهاى كبدى (الف) آنزيم ALT، (ب) آنزيم AST، (ج) آنزيم .ALP

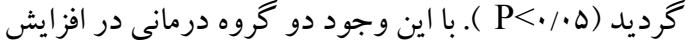

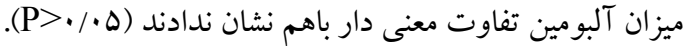

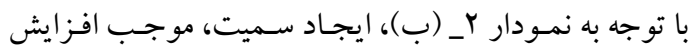

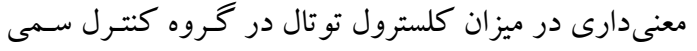

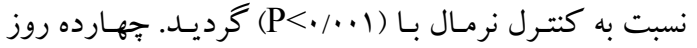

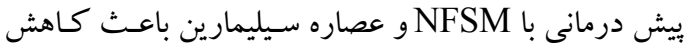

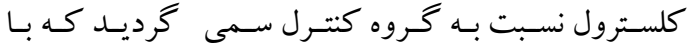

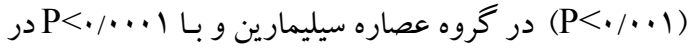

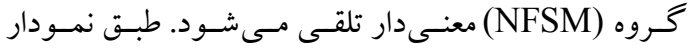
r ب (ب)، ييش درمانى با نانوميسل نسبت به عصاره سيليمارين

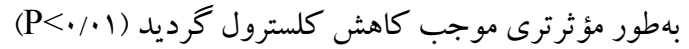

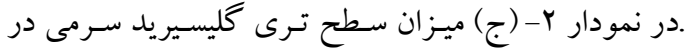

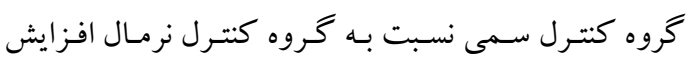

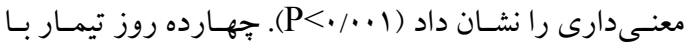

نتايج بر اساس Mean \pm نمايش دادهشداند. (*) نشاندهندهى تفاوت معنى دار بين گروه كنترل سمى با لـانج كروه كنترل نرمال، (\#) نشاندهنده تفاوت معنى دار بين

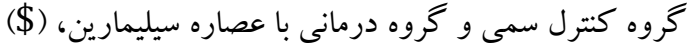

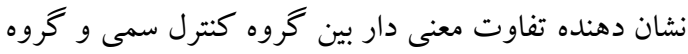

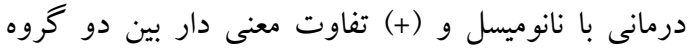

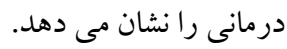
همانطور كه در نمودار Y (الف) ملاحظه مى گرددد، تزريق

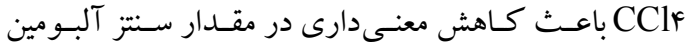

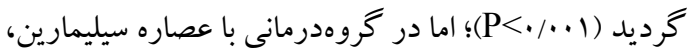

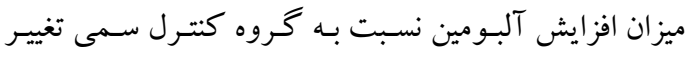

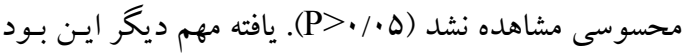
كه تجويز نانوميسل سيليمارين (NFSM) بهطور معنىدارى

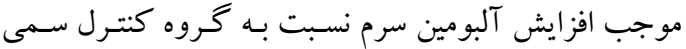




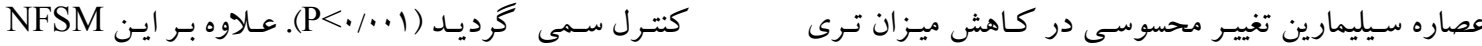

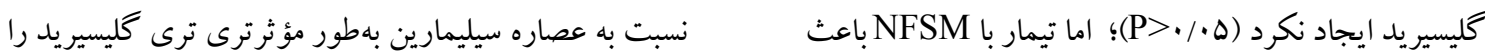

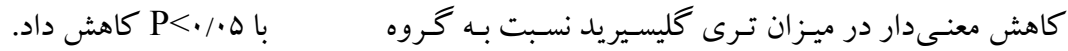
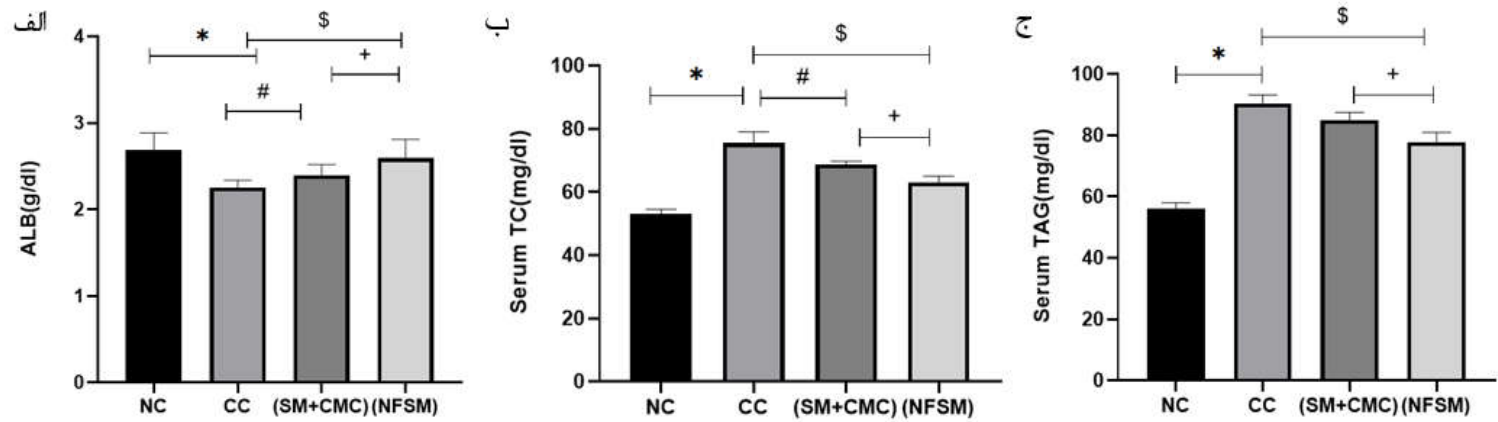

نمودار ז. اثر نانوميسل خوراكى در مقايسه با عصاره سيليمارين بر پارامترهاى ييوشيميايى (الف) آلبومين، (ب) كلسترول توتال، (ج) ترى تليسيريد.

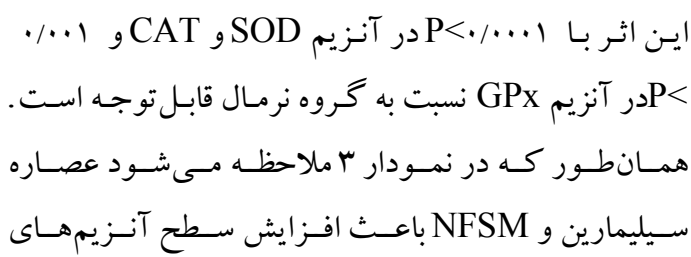

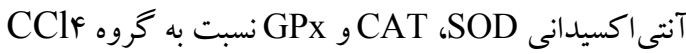

كرديد. نانوميسل سيليمارين در مقايسه بـا عصاره آن باعثى

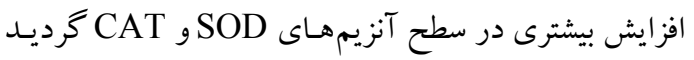

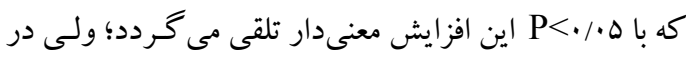

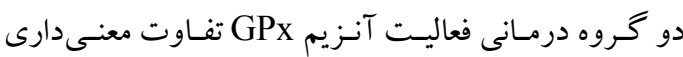

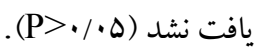
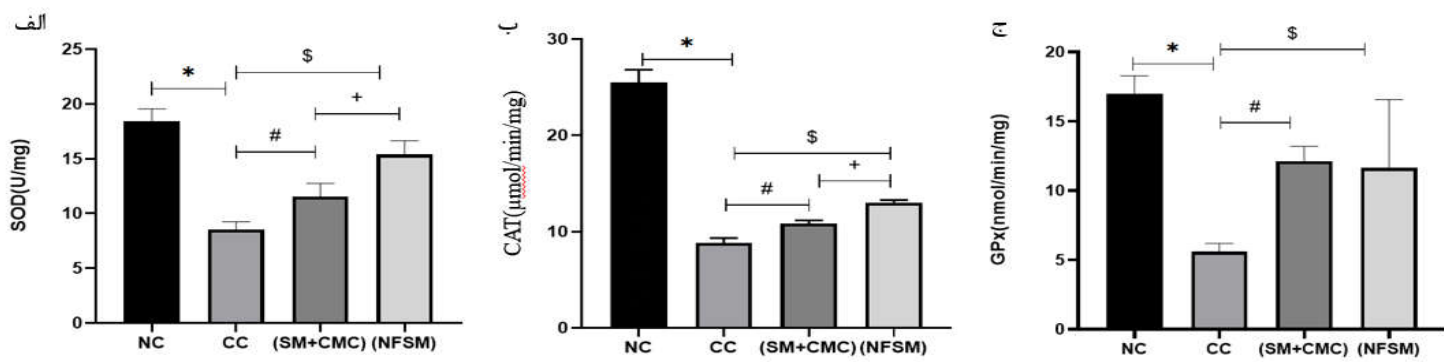

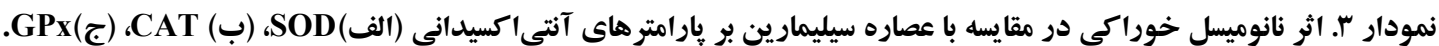




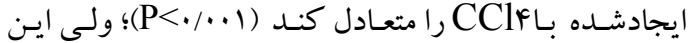

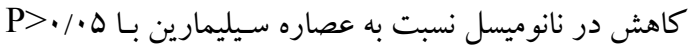
معنى دار نيست؛ بنابر اين تفاوت قابـل توجهى بـين دو گُروه

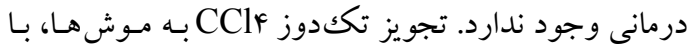

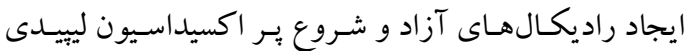
باعث افزايش قابـل توجهى در سطح MDA در مقايسه بـا

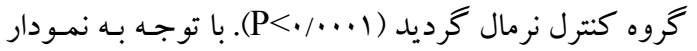
ץ-(ب) تجـويز عصـاره سـيليمارين و نانوميسل سـيليمارين بهصورت ييش درمانى، سطح MDA را در مقايسه بـا گرووه

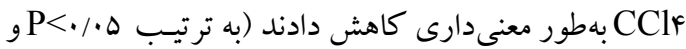

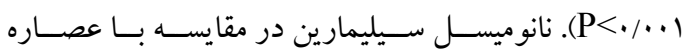

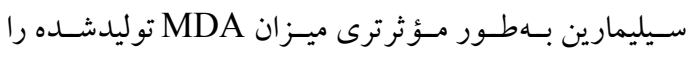

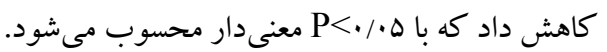

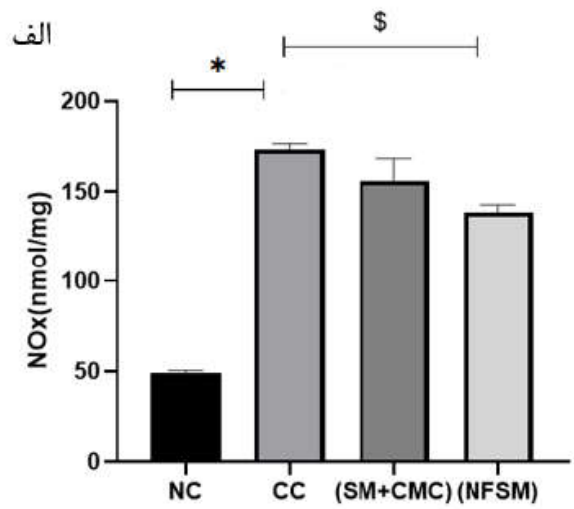

نتايج بر اساس Mean \pm نمايش دادهشدهاند. (*) نشاندهندهى تفاوت معنى دار بين گروه كنترل سمى با گروه كنترل نرمال، (\#) نشاندهنده تفاوت معنىدار بين گروه

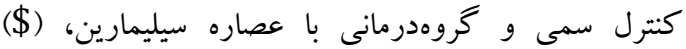
نشاندهنده تفاوت معنىدار بين گروه كنترل سمى با كروهدرمانى نانوميسل و (+) تفاوت معنىدار بين دو لغنات كروهدرمانى را نشان مى مهدود. همانطور كه در نمودار F (الف) ملاحظه مى گردد، محتواى سلولهاى كبدى در گروه CClF دO مر مقايسه بـا خروه

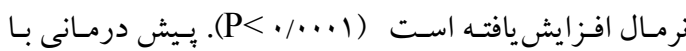
عصاره سـيليمارين تغيير محسوسى در ميزان محتواى NO

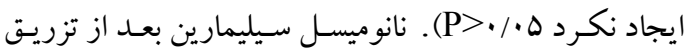
تCl؟ توانسـت محتـواى NOx افـزايش يافتـه در سـميت

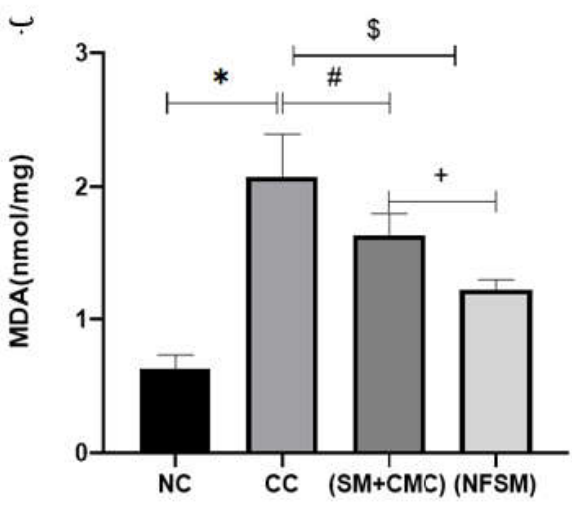

نمودار f. اثر نانوميسل خوراكى در مقايسه با عصاره سيليمارين بر هارامترهاى استرس اكسيداتيو(الف)NOx، (ب) MDA.

سيليمارين يكك يلى فنول گياهى است كه بـ دليـل خـواص آنتى اكسيدانى در درمان اختلالات كبدى استفاده مسى شـود. بااين حال، سـيليمارين در آب نـامحلول اسـت كـه عمـدتاً بـهـ دليل ساختار شديد هيدروفوبى و غير يـونى آن استـ. ايـن

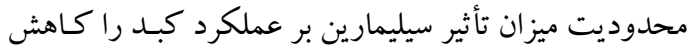

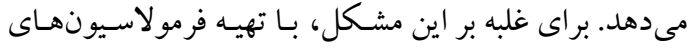

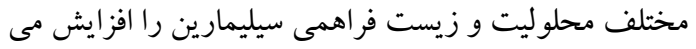

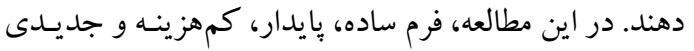
از سيليمارين (NFSM) به شكل نانو ميسل با قابليـت انحـلال
نتايج بر اساس Mean士SD نمايش دادهشداند. (*) نشاندهندهى تفاوت معنى دار بين گروه كنترل سمى با گروه كنترل نرمال، (\#) نشاندهنده تفاوت معنىدار بين گرُوه

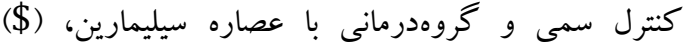
نشاندهنده تفاوت معنىدار بين گروه كنترل سمى و گرووه

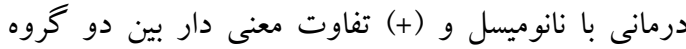

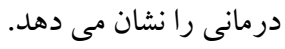




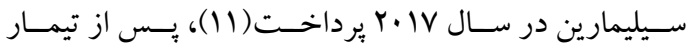

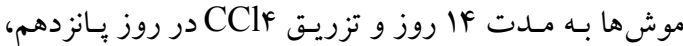
ميزان آلبومين سرم اندازه گيرى شد؛ كه در گروه تيمار شـده با سيليمارين افزايش مقدار آلبومين نسبت بـه گـروه كنتـرل سـمى نشـان داده شـد؛ امـا در مطالعـه حاضـر، ميـزان سـطح آلبومين در گروه تيمار با عصـاره سـيليمارين تفـاوت معنسى دارى نسبت به گروه CClF يافت نشد(ه • • P>). عدمتغير در ميزان آلبـومين در گحروه تيمـار بـا عصـاره سـيليمارين مسىتوانـد بـه دليـل جـذب رودهاى ناكـافى سـيليمارين و درنتيجه غلظـت يـايين آن در خـون اســ؛ كـه قـادر بـه تحريكك افزايش بيان زن ALB نيست. بـا ايسن وجـود يافتـه مهم اين مطالعه اين بود كه درمان با NFSM باعث ممانعـت از كاهش مقدار آلبومين نسبت به گروه كنترل سمى گرديد كه اين امر مىتواند به دليل افزايش محلوليت و جذب بيشـر و د درنتيجه تأثير بيشتر بر سلولهاى كبـدى از طريـق اسـتحكام بخشـيدن بـه شـبكه آندويّلاسـمى و سـنتز دوبـاره يروتئين و يا از طريق خنثى كردن ROS بهوسيله اين محلـول

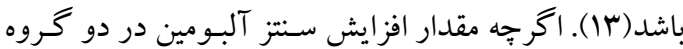

تيمار تفاوت قابل محسوسى را نشان نمى دهد (ه • P> P).

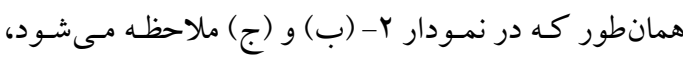
تزريـت CClF باعـث افـز ايش قابـلـتوجـهـ در TG و TC CClF مسىشـود. افـزايش سـطح كلسـترول بعـد از تزريست مسى توانــ ناشـى از افـزايش اسـترىشـــن اسـيدهاى جـرب، ممانعت از بتا اكسيداسيون اسيدهاى جرب و كاهش خـروج و دفع ليبيدهاى سلولى باشد(f أ). در يكك مطالعـه نشـان داده شده است كه سيليمارين با مهار آنزيم ب-هيدرو كسى س-متيل

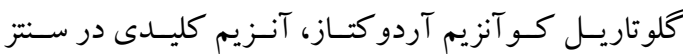

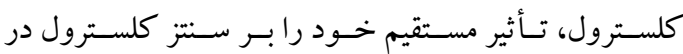

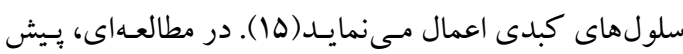
درمانى با سيليمارين به مدت fا ا روز و سـبس ايجـاد سـميت بـClF CCL، باعـث كـاهش كلسـترول و تـرى كليسـيريد بـا

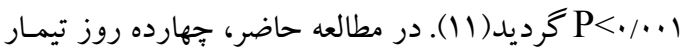
بـا نانوميسـل ســليمارين باعـث كـاهش كلسـترول و تـرى
و جذب بيشتر تهيه شد. با توجه به نتايج بهدست آمـده از ايـن مطالعه مشاهده شد كه بس از تيمار موشهـاى صسحرايى بــ

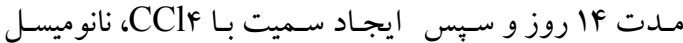
سيليمارين در مقايسه بـا عصـاره آن بـهـور مـؤثرى موجـبـ افزايش حفاظت كبدى در برابر سميت CClF مى گردد. در مطالعه حاضر، سطح سرمى سـه آنزيم كبـدى، در هـر دو كروه درمانى (عصاره سيليمارين و نانوميسل) نسبت به گروه كنترل سمى (كروه تيمار نشده) كاهش قابل تـوجهى داشـتند كه اين كاهش با هـ/P> Pعنىدار تلقى مسىشود كـه نشـان مـىدهـــ تجـويز خـوراكى عصـاره سـيليمارين و نانوميسل سـيليمارين باعـث حفاظـت هياتوسـيت هـا در برابـر سـميت CClF و باز گشت سلول ها بـه سـمت نرمـال شـدن مسىشـود. همانطور كه از دادهها مشخص است، نانوميسـل سـيليمارين اثر بهبودى بيشترى را نسبت به عصـاره سـيليمارين در آنزيم نشان مى AST و ALT محلوليـت و اثربخشـى ايسن نانو ميسـل نسـبت بـه عصـاره سيليمارين باشد. اين يافته بـا مطالعـات صـورت كرفتـه قبلى همراستا است(11, ·1). در مطالعهاى كه توسط Parveen و همكاران (Y.11) بر روى نـانو امولسـيونى حساوى سـيليمارين انجام گرفت، بِ از تيمار رت هـا بـه مـــت هـ روز و تزريـق CClF انـدازه گيـرى شـد. نتـايج كـاهش معنسى دارى در ميـزان ايسن يارامترها نشان داد(Y I). در مطالعهاى ديخر، ميزان آنزيمهاى كبدى يس از سه روز تيمار با نانو امولسيونى از سـيليمارين و سـبس ايجـاد سـميت در مـوشهـا مـورد انـدازه خيـرى قـرار كرفت( •(1). نتايج نشان داد ميزان آنزيمهـاى كبـدى يس از

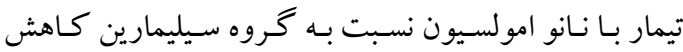

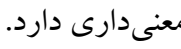
كبد جايگاه اصلى سنتز يروتئينها بهخصوص آلبومين اسـت.

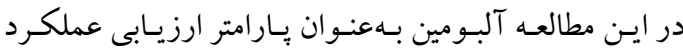
سنتزى كبد در نظر كرفتـه شـده اسـت. در مطالعهاى كـه بـهـ TPE بررسى مقايسهاى حفاظت كبدى سيليمارين با تر كيب (عصاره Tanacetum Parthenium) در مقايسه با عصـاره 
كنتـرل سـمى گرديــ(1) (1). Wang و همكــاران (ها •r) در مطالعهاى، بـه بررسى اثر آنتىاكسيدانى برولييـوزومى از

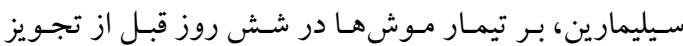

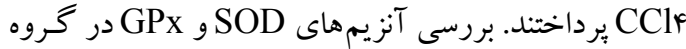
درمانى با برولييوزوم سيليمارين در مقايسه بـا خروه كنترل

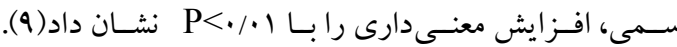
همجِنين نتايج مطالعه مـا نشان داد كه دو گرووه درمانى در ميزان فعاليت آنزيم GPx تفاوت معنىدارى ندارند كه شايد

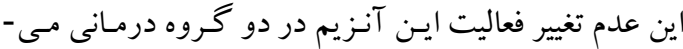
تو اند به علت كو تاه بودن دوره درمان و يا عـدم دوز مناسـب لئب

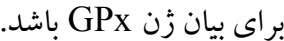

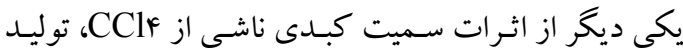

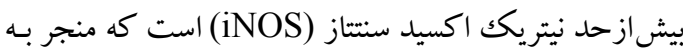
توليد نيتريك اكسيد در كبد و افزايش استرس نيتروزاتيو و آسيب بافتى مى شود(19). در ايـن راستا، يافتههـاى مطالعـه

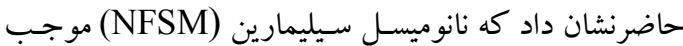

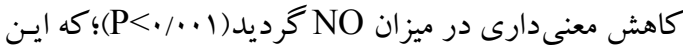
امر مىتواند به دليل افزايش حلاليت و نفوذيذيرى نانوميسل باشد. با اين وجود نانوميسل سيليمارين تفـاوت معنسدارى نسبت بـه گحروه درمـان شـده بـا عصـاره سيليمارين ايجـاد

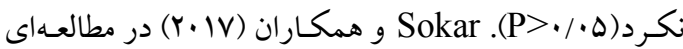

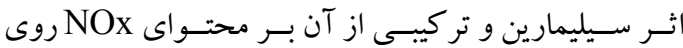
فيبروز كبدى يس از تيمار مـوشهـا بـه مـدت V هفتـه، نشـان دادكه ميزان NO در گحروه كنترل سـمى نسبت بـه گحروه

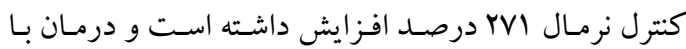
سيليمارين و تركيب آن باعث كاهش قابـل توجـه در مقـدار محتواى NO (به ترتيب ro و و و درصد) مى گردد (1).

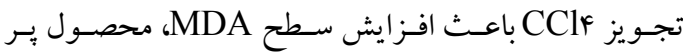

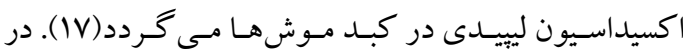
مطالعه حاضر تجويز تكك دوز CClF بـه مـوشهـا، بـا ايجـاد

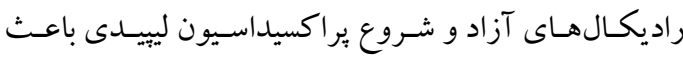

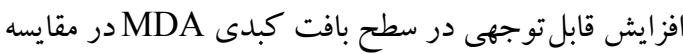

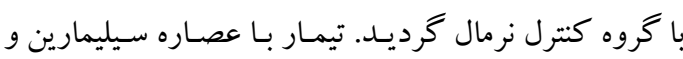

كليسير يد نسبت به گروه CClF شد. علاوه بر اين نانوميسل

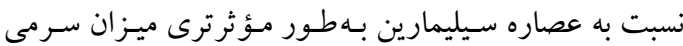

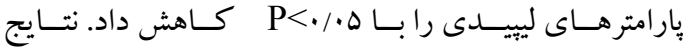
بهدست آمده از اين بثروهش همراستا با مطالعات قبلى مى - بـ باشد (1), 10). اين امر مىتواند بهعلت افزايش محلوليت؛ و

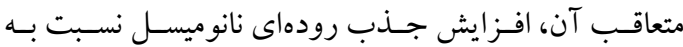
عصاره سيليمارين باشد. بنابراين، تجويز نانوميسل سيليمارين

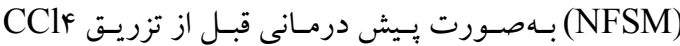
بهوطور مؤثرترى مى توانـد ميزان بِروفايـل ليييـدى را متعـادل كند. بدن بهور مؤثرى مكانيسمهاى دفاعى در برابر راديكالهاى

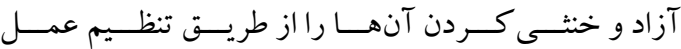
آنتى اكسيدانى داخـل سـلولى آنزيمهـايى مانــــ كلوتاتيون يراكسـيداز، سوير اكسيد ديس موتـاز و كاتـالاز دارد. ايسن

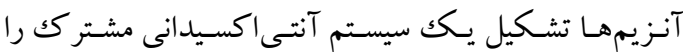
مى دهند(19). در آسيب القاشـده بـه وسيلهى CClF، تعادل بين ميزان توليـ ROS و سيستم دفاع آنتى اكسيدانى اين

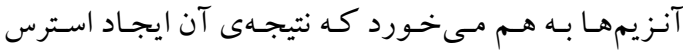
اكسيداتيو و اختلال عملكرد سلولى و آسيب كبدى و نهايتاً نكروز استـ(IV). يافتههـاى مطالعه مـا نشـان داد، عصاره

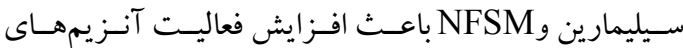

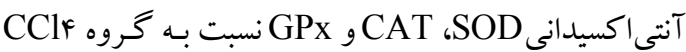
كرديد. مطالعات قبلى نشـان دادهاندكه سيليمارين قادر بـه تحريكك آنزيمهـاى آنتى اكسـيدانى و همجنسين خاصسيت

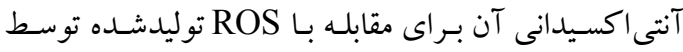
CClF

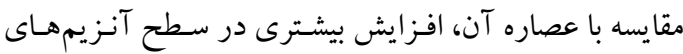
نشان داد؛ كه اين افزايش با هـ/CAT و SOD محسوب مى شود. نتايج به دست آمده از اين آنزيمها همسو

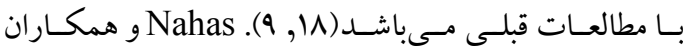
(Y.IV)

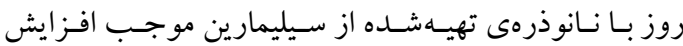
آنزيمهاى آنتى اكسيدانى بهصورت معنى دار نسبت بـه خروه تهره 


$$
\begin{aligned}
& \text { در ايــن مطالــه شــكل جديسـدى از محلــول ســيليمارين }
\end{aligned}
$$

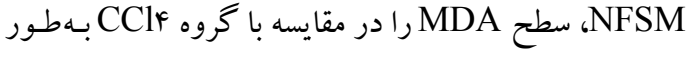

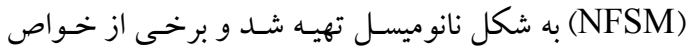

$$
\begin{aligned}
& \text { معنىدارى كاهش داد. نانوميسل سيليمارين بهطور مـؤثرترى } \\
& \text { دارويى آن مورد ارزيابى قرار گرفت. بررسى كلى اين نتايج } \\
& \text { موجـب كـاهش سـطح MDA نسـبت بـه گـروه عصـاره }
\end{aligned}
$$

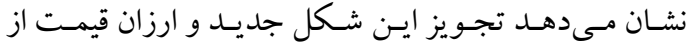

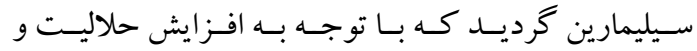

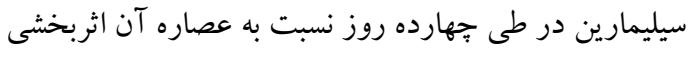

$$
\begin{aligned}
& \text { نفوذيــيرى نانوميسـل قابـل توجيـه اسـتـ ايـن يافتـهـــا در } \\
& \text { CClF بيشترى بر حفاظت سلولهـاى كبـدى در سـميت بـان }
\end{aligned}
$$

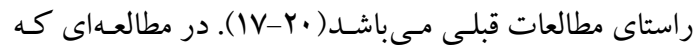

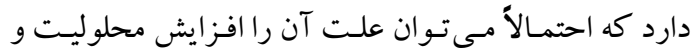

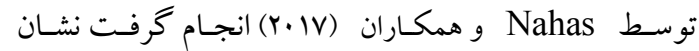

$$
\begin{aligned}
& \text { جـــب رودهاى نانوميسـل برشــمرد. بـاين حــال ايـن ميـزان }
\end{aligned}
$$

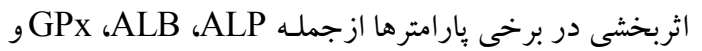

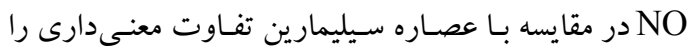

$$
\begin{aligned}
& \text { نشان نداد، كه شايد مى تواند به دليل كوتاه بودن دوره درمان } \\
& \text { و يا عدم دوز مناسب سيليمارين در گروههاى درمانى باشــ؛ } \\
& \text { بنابر اين براى در كك بهتر نتايج، بـه مطالعـات بيشترى در در ايسن }
\end{aligned}
$$

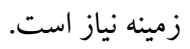

$$
\begin{aligned}
& \text { داده شده است كه درمان با نانوذرهاى از سيليمارين بـه مـدت } \\
& \text { سه روز، موجب كاهش معنى دار در ميزان MDA بـا اـ/. }
\end{aligned}
$$

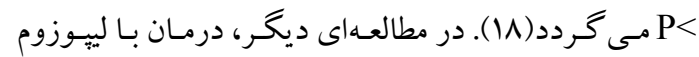

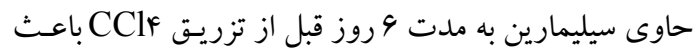

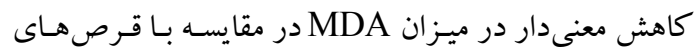

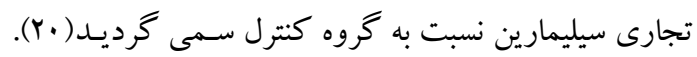

$$
\begin{aligned}
& \text { برخى مطالعات نشان دادهاند كه سيليمارين مى تواند به دليل خرول }
\end{aligned}
$$

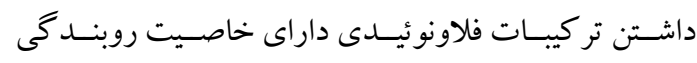

$$
\begin{aligned}
& \text { تشكر و قدردانى }
\end{aligned}
$$

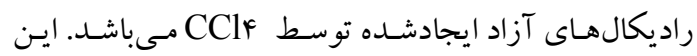

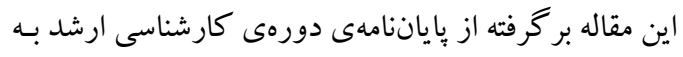

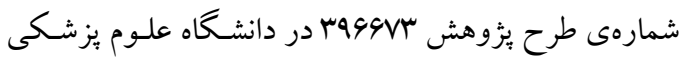

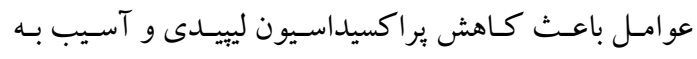

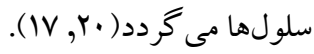

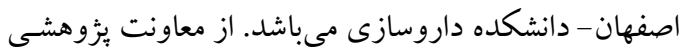

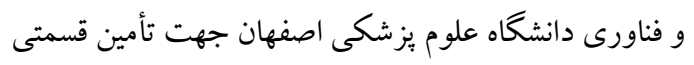

$$
\begin{aligned}
& \text { از هزينهاى اين طرح قدردانى مى شوداد. }
\end{aligned}
$$

1.Sokar SS, El-Sayad ME-S, Ghoneim ME-S, Shebl AM. Combination of Sitagliptin and Silymarin ameliorates liver fibrosis induced by carbon tetrachloride in rats. Biomed Pharmacother. 2017;89:98107.

2.Setty SR, Quereshi AA, Swamy AV, Patil T, Prakash T, Prabhu K, et al. Hepatoprotective activity of Calotropis procera flowers against paracetamol-induced hepatic injury in rats. Fitoterapia. 2007;78(78):451-4.

3.Di Costanzo A, Angelico R. Formulation strategies for enhancing the bioavailability of silymarin: the state of the art. Molecules. 2019;24(11):2155.

4.D’Archivio M, Filesi C, Varì R, Scazzocchio B, Masella R. Bioavailability of the polyphenols: status and controversies. Int J Mol Sci. 2010;11(4):1321-42.

5.Pandey KB, Rizvi SI. Plant polyphenols as dietary antioxidants in human health and disease. Oxid Med Cell Longev. 2009;2(5):270-8.

6.Feng B, Meng R, Huang B, Shen S, Bi Y, Zhu D. Silymarin alleviates hepatic oxidative stress and protects against metabolic disorders in high-fat diet-fed mice. Free Radic Res. 2016;50(3):314-27. 
11

7.Esposito T, Sansone F, Russo P, Picerno P, Aquino RP, Gasparri F, et al. A water-soluble microencapsulated milk thistle extract as active ingredient for dermal formulations. Molecules. 2019;24(8):1547.

8.Passerini N, Perissutti B, Albertini B, Franceschinis E, Lenaz D, Hasa D, et al. A new approach to enhance oral bioavailability of Silybum Marianum dry extract: Association of mechanochemical activation and spray congealing. Phytomedicine. 2012;19(2):160-8.

9.Abdel-Moneim AM, Al-Kahtani MA, El-Kersh MA, Al-Omair MA. Free radical-scavenging, antiinflammatory/anti-fibrotic and hepatoprotective actions of taurine and silymarin against CCl4 induced rat liver damage. PLoS One. 2015;10(12):e0144509.

10.Guhagarkar SA, Shah D, Patel MD, Sathaye SS, Devarajan PV. Polyethylene sebacate-silymarin nanoparticles with enhanced hepatoprotective activity. J Nanosci Nanotechnol. 2015;15(6):4090-3.

11. Mahmoodzadeh Y, Mazani M, Rezagholizadeh L. Hepatoprotective effect of methanolic Tanacetum parthenium extract on CCl4-induced liver damage in rats. Toxicol Rep. 2017;4:455-62.

12.Parveen R, Baboota S, Ali J, Ahuja A, Vasudev SS, Ahmad S. Oil based nanocarrier for improved oral delivery of silymarin: in vitro and in vivo studies. Int J Pharm. 2011;413(1-2):245-53.

13.Dufour C, Loonis M, Dangles O. Inhibition of the peroxidation of linoleic acid by the flavonoid quercetin within their complex with human serum albumin. Free Radic Biol Med. 2007;43(2):241-52.

14.Fernandez ML, West KL. Mechanisms by which dietary fatty acids modulate plasma lipids. J Nutr. 2005;135(9):2075-8.

15.Krečman V, Škottová N, Walterová D, Ulrichová J, Šimánek V. Silymarin inhibits the development of diet-induced hypercholesterolemia in rats. Planta Medica. 1998;64(02):138-42.

16.Liu W, Baker SS, D Baker R, Zhu L. Antioxidant mechanisms in nonalcoholic fatty liver disease. Curr Drug Targets. 2015;16(12):1301-14.

17.Nencini C, Giorgi G, Micheli L. Protective effect of silymarin on oxidative stress in rat brain. Phytomedicine. 2007;14(2-3):129-35.

18.El-Nahas AE, Allam AN, Abdelmonsif DA, El-Kamel AH. Silymarin-loaded eudragit nanoparticles: formulation, characterization, and hepatoprotective and toxicity evaluation. Aaps Pharmscitech. 2017;18(8):3076-86.

19.Singh H, Sidhu S, Chopra K, Khan M. The novel role of $\beta$-aescin in attenuating CCl4-induced hepatotoxicity in rats. Pharm Biol. 2017;55(1):749-57.

20.Wang M, Xie T, Chang Z, Wang L, Xie X, Kou Y, et al. A new type of liquid silymarin proliposome containing bile salts: its preparation and improved hepatoprotective effects. PLoS One. 2015;10(12):e0143625. 